\title{
Export Diversification and Economic Growth in Nigeria
}

\author{
Philip Ifeakachukwu Nwosa ${ }^{1^{*}}$, Fasina Oluwadamilola Tosin ${ }^{2}$, \\ Ogbuagu Matthew Ikechukwu ${ }^{3}$ \\ ${ }^{*}$ Corresponding author
}

\begin{abstract}
The issue of export diversification has been contentious in Nigeria due to the country's unstable growth pattern which is majorly associated with instability in the international oil market and the poor performance of other sectors of the economy. Therefore, this study examines the link between export diversification and economic growth in Nigeria from 1962 to 2016. The study utilizes the Auto-regressive Distributed Lag (ARDL) technique. The result of this study shows that export diversification has a positive but insignificant influence on economic growth in Nigeria. The above result implies that the oil sector still dominates the Nigerian economy while the diversification drive of the government has not been significant in other sectors of the economy. Thus, the study recommends the need for conscious economic policies that would promote the diversification of the entire non-oil sector of the economy. The study concludes that export diversification is an insignificant determinant of economic growth in Nigeria.
\end{abstract}

Keywords: export diversification, economic growth, auto-regressive distributed lag

\begin{abstract}
Abstrak
Masalah diversifikasi ekspor telah diperdebatkan di Nigeria, karena pola pertumbuhan negara yang tidak stabil yang sebagian besar terkait dengan ketidakstabilan di pasar minyak internasional dan buruknya kinerja sektor-sektor ekonomi lainnya. Oleh karena itu, penelitian ini meneliti hubungan antara diversifikasi ekspor dan pertumbuhan ekonomi di Nigeria dari tahun 1962 hingga 2016. Penelitian ini menggunakan teknik Auto-regressive Distributed Lag (ARDL). Hasil penelitian ini menunjukkan bahwa diversifikasi ekspor memiliki pengaruh positif tetapi tidak signifikan terhadap pertumbuhan ekonomi di Nigeria. Hasil di atas menyiratkan bahwa sektor minyak masih mendominasi ekonomi Nigeria sementara dorongan diversifikasi pemerintah belum signifikan di sektor-sektor ekonomi lainnya. Dengan demikian, studi ini merekomendasikan perlunya kebijakan ekonomi sadar yang akan mempromosikan diversifikasi seluruh sektor ekonomi non-minyak. Studi ini menyimpulkan bahwa diversifikasi ekspor merupakan faktor penentu yang tidak signifikan terhadap pertumbuhan ekonomi di Nigeria.
\end{abstract}

Kata Kunci: diversifikasi ekspor, pertumbuhan ekonomi, auto-regressive distributed lag JEL Code: C32, F16, O47

\section{How to Cite:}

Nwosa, P. I., Tosin, F. O., \& Ikechukwu, O. M. (2019). Export Diversification and Economic Growth in Nigeria. Signifikan: Jurnal Ilmu Ekonomi, Vol. 8(2), 227-234. doi: http://dx.doi.org/10.15408/sjie.v8i2.9861. 


\section{Introduction}

The unstable growth performance of the Nigerian economy has been a source of concern to policymakers due to the dominance of crude oil as the mainstay of the Nigerian economy (in terms of export share and foreign exchange earnings), instability in international crude oil price, neglect of other sectors (agricultural, manufacturing and service) of the economy, narrow base of the country's export and foreign exchange earnings, and political unrest/ agitation in oil exploring communities among others. Consequently, export diversification presents a viable option for addressing the above issues and the attainment of sustainable growth and even development across the country.

The idea of export diversification is a two in one approach: The first approach is a total drift from the old system while the second approach is maximizing the new system into diverse purposes for economic growth and development (Iniodu, 1995, Suberu et al., 2015). Diversifying an economy comes alongside with market or trade diversification, export diversification, investment diversification, and any other form of diversification leading to sustainable economic growth and development. Studies have shown that export diversification has implication on macroeconomic variables such as favourable balance of payment, reduced unemployment and poverty rate, rising investment level and economic growth (Agosin, 2007; Herzer \& Nowak-Lehnmann, 2006). Also Studies have noted that export diversification reduces macroeconomic challenges in the achievement of sustainable foreign exchange earnings and economic growth which is linked to the over dependence of a country on a particular commodity export such as crude oil (Kardyrova, 2011).

The importance of export diversification has prompted scholars in examining the link between export diversification and economic growth. However, most studies on this issue are center on developed and other less developed countries (Aamir, 2018; Agosin, 2007; Herzer \& Nowak-Lehnman, 2006) with little or no empirical study exist concerning Nigeria. The very few papers on Nigeria are either descriptive (Nworu, 2017) or are focused on the link between non-oil export and economic growth (Esu \& Udowa, 2015; Olayiwola \& Okodua, 2013; Olaleye et al., 2013). Consequently, the perusal of the literature shows the existence of a dearth in knowledge on the link between export diversification and economic growth in Nigeria.

Thus, this study intends to fill the research gap by empirically examining the relationship between export diversification and economic growth in Nigeria. Examining this issue is vital because the outcome of this study will aid policymakers on future export diversification agenda of the government and will also reveal if the Nigerian economy is on the path of sustainable growth and development. Besides, this study also to evaluate the importance of export diversification as a determinant of economic growth in Nigeria. Given the intense drive of the government towards the path of sustainable economic growth and development. Also, this study employs the export diversification index obtained from the International Monetary Fund (IMF) bulletin as a measure of export diversification. To the best knowledge of the authors, no indigenous study has employed this index of export diversification, and empirical studies have shown the appropriateness of this index in capturing the export diversification of a country. 
The purpose of this study is to examine the relationship between export diversification and economic growth in Nigeria over the period 1962 to 2016. The rest of the paper is as follows. The review of literature is presented in section two while section three discussed the research methods. Section four presents the results and findings of the study while section five presents the discussion of the regression estimate. Based on the research findings, section six discussed the conclusion and policy recommendations.

\section{Method}

This study adopts the neoclassical growth model to examine the link between export diversification and economic growth. The equation as follows:

$$
Y=f\left(K^{\alpha}, L^{\beta}, A\right)
$$

Equation (1) is an augmented Cobb-Douglas production function where: $\mathrm{Y}$ is the growth rate of the gross domestic product; $\mathrm{L}$ is labor; $\mathrm{K}$ is capital formation; and $\mathrm{A}=$ total factor productivity (TFP). Introducing export diversification and other controlled variables that have identified as important determinants of economic growth, equation (1) becomes:

$$
\begin{aligned}
\operatorname{lnY_{t}}= & \alpha_{0}+\alpha_{1} \operatorname{lnK}_{\mathrm{t}}+\alpha_{2} \operatorname{lnL}_{\mathrm{t}}+\alpha_{3} \operatorname{lnDIV}_{\mathrm{t}}+\alpha_{4} \operatorname{lnMS}_{\mathrm{t}}+\alpha_{5} \operatorname{lnINT}_{\mathrm{t}}+\alpha_{6} \operatorname{lnEXR}_{\mathrm{t}} \\
& +\alpha_{7} \operatorname{lnIN\mathrm {I}_{\mathrm {t}}}+\varepsilon_{\mathrm{t}}
\end{aligned}
$$

Where $\alpha_{0}$ represents a constant parameter and $\varepsilon_{\mathrm{t}}$ is the error term. Theoretically, capital (K), labor (L), export diversification (DIV) money supply (MS) and exchange rate (EXR) are expected to have positive impact on economic growth while interest rate (INT) is expected has to have an inverse relationship with economic growth. The expected link between inflation rate and economic growth remains indeterminate.

In this study, economic growth is proxy by real gross domestic product. Money Supply (MS) measure by the broad money supply, it also known as M2. The inflation rate (INF) is proxy by Consumer Price Index (CPI). Exchange Rate (EXR) is measure by the official Naira to US dollar ( 1 / ) exchange rate, and Interest Rate (INT) is measure by the monetary policy rate which is a short term interest rate. The data are obtained from the Central Bank of Nigeria Annual Statistical Bulletin (CBN). Export diversification (DIV) is measure by export diversification and the data obtained from the International Monetary Fund (IMF) database. The data are analyzed using the Auto-regressive distributed lag (ARDL) technique. This technique allows the estimation of variables that are both $\mathrm{I}(1)$ and $\mathrm{I}(0)$. The outcome of the ARDL technique also shows both the long and short-run relationship between the estimated variables.

\section{Results and Discussion}

The descriptive statistics of the variables presents in Table 1 . Table 1 shows that the average values of the real gross domestic product (LRGDP), export diversification (DIV), money supply (LMS) and inflation rate (INF) are 10.07, 5.8, 5.12 and 18.55 respectively. While, the average values of the exchange rate (EXR), interest rate (INT), the labor force (LLAB) and capital stock (LCAP) are 58.82, 10.97, 17.34 and 10.64 respectively. The standard deviation estimate from the descriptive statistics shows that exchange rate (EXR) (70.75) was the most volatile among the variables, while export diversification (DIV) (0.27) was the least volatile variable. 
Table 1. Descriptive Statistics

\begin{tabular}{lcccccccc}
\hline Variables & LRGDP & DIV & LMS & INF & EXR & INT & LLAB & LCAP \\
\hline Mean & 10.07 & 5.89 & 5.12 & 18.55 & 58.82 & 10.97 & 17.34 & 10.64 \\
Std. Dev. & 0.69 & 0.27 & 3.17 & 16.79 & 70.75 & 5.05 & 0.28 & 2.07 \\
Skewness & -0.65 & -2.71 & 0.00 & 1.66 & 0.82 & 0.44 & 0.26 & 1.28 \\
Kurtosis & 3.47 & 12.13 & 1.76 & 4.84 & 2.38 & 3.02 & 1.63 & 5.09 \\
Jarque-Bera & 3.72 & 220.52 & 3.00 & 28.17 & 6.00 & 1.50 & 4.23 & 21.43 \\
Probability & 0.16 & 0.00 & 0.22 & 0.00 & 0.05 & 0.47 & 0.12 & 0.00 \\
\hline
\end{tabular}

Source: Data processing

The skewness statistics show that real gross domestic product (LRGDP) and export diversification (DIV) negatively skewed while the money supply (LMS), inflation rate (INF), exchange rate (EXR), interest rate (INT), labor force (LLAB) and capital stock (LCAP) were positively skewed. The kurtosis statistics show that real gross domestic product (LRGDP), export diversification (DIV), inflation rate (INF) and capital stock (LCAP) were leptokurtic, suggesting that their distributions were peak relative to normal distribution. While money supply (LMS), the exchange rate (EXR), and labor force (LLAB) were platykurtic, this implies that the distribution was flat relative to normal distribution.

However, the distribution of interest rate (INT) is mesokurtic, and it implies that the variable had a normal distribution. Finally, the Jarque-Bera statistic rejects the null hypothesis of the normal distribution for export diversification (DIV), inflation rate (INF), the exchange rate (EXR), and capital stock (LCAP). This result shows that the variables normally distributed while the Jarque-Bera statistic did not reject the null hypotheses for the remaining variables (real gross domestic product (LRGDP), money supply (LMS), interest rate (INT) and labor force (LCAP).

Table 2. Unit Root Test

\begin{tabular}{lccc}
\hline Variables & Level & $1^{\text {st }}$ Difference & Status \\
\hline LRGDP & 1.8325 & -7.0748 & $\mathrm{I}(1)$ \\
DIV & -6.5933 & - & $\mathrm{I}(0)$ \\
LMS & -0.9841 & -3.5618 & $\mathrm{I}(1)$ \\
INF & -3.5869 & - & $\mathrm{I}(0)$ \\
EXR & -2.0148 & -4.0346 & $\mathrm{I}(1)$ \\
INT & -2.2967 & -7.0592 & $\mathrm{I}(1)$ \\
LLAB & -0.3788 & -6.0664 & $\mathrm{I}(1)$ \\
LCAP & -0.5704 & -6.8927 & $\mathrm{I}(1)$ \\
\hline
\end{tabular}

Source: Data processing.

Note: ${ }^{*}$ implies one percent significance level.

The unit root of the variables is conducted using the Augmented Dickey-Fuller test. The result from Table 2 shows that all variables with exception to export diversification (DIV) and inflation rate (INF) were I(1) series while export diversification (DIV) and inflation rate (INF) were stationary at level, implying that the variables were $\mathrm{I}(0)$ series. 
Table 3. ARDL Bound Co-integration Test

\begin{tabular}{ccc}
\hline $\begin{array}{l}\text { Estimated Model } \\
\text { GROWTH-DIV Model }\end{array}$ & \multicolumn{2}{l}{$\begin{array}{l}\text { F-Statistics } \\
3.8402^{* *}\end{array}$} \\
\hline Critical Values & Lower Bound & Upper Bound \\
\hline $1 \%$ & 2.96 & 4.26 \\
$5 \%$ & 2.32 & 3.5 \\
\hline
\end{tabular}

Source: Data processing

Sequel to the mix in the result of the unit root tests presented in Table 2, this study carries out the co-integration test using the Auto-Regressive Distributed Lag Bound Co-integration test. From the co-integration result presented in Table 3 show that the value of the F-statistics for the estimating model of equation (3) is higher than the upper bound critical value at $5 \%$. This result is suggesting the existence of co-integration among the variables in the model.

The regression $s$ the link between export diversification and economic growth with money supply, inflation rate, exchange rate, interest rate, labor force, and capital stock as explanatory variables presented in Table 4. The F-statistics of the model is significant 60.80 $(\mathrm{p}<0.05)$ at five percent level of significance. The explanatory power of the model (R-squared) is 0.91 , indicating that the explanatory variables of the model explained jointly about $91 \%$ of the variation in economic growth while the remaining about $9 \%$ explained by other variables that not included in the model. The value of the Durbin Watson (1.78) shows the absence of serial autocorrelation in the regression estimate. From the regression estimate, it observes that export diversification (DIV) had a positive but insignificant impact on economic growth in Nigeria.

Table 4. ARDL Estimate on Export Diversification and Economic Growth in Nigeria

\begin{tabular}{llllll}
\hline Dependent Var. & Regressors & Est. Coef. & Stand. Error & t-Stat & Prob. \\
\hline LGDP & C & -73.3173 & 13.3169 & -5.5056 & 0.0000 \\
& DIV & 0.0050 & 0.0265 & 0.1877 & 0.8521 \\
& LMS & 0.2257 & 0.0701 & -3.2224 & 0.0026 \\
& INF & -0.0046 & 0.0022 & -2.0746 & 0.0447 \\
& EXR & -0.0009 & 0.0015 & -0.6525 & 0.5179 \\
& INT & -0.0187 & 0.0090 & -2.0725 & 0.0449 \\
& LLAB & 4.4885 & 0.7741 & 5.7986 & 0.0000 \\
& LCAP & 0.0631 & 0.0257 & 2.4586 & 0.0185 \\
& ECT $(-1)$ & -1.2383 & 0.3532 & -3.5061 & 0.0393 \\
\hline R-Square $=0.91$ & & & & Adjusted R-Square $=0.90$ \\
F-Stat. (Prob.) = 60.8019 (0.000) & & & Durbin-Watson Stat. $=1.78$ \\
\hline
\end{tabular}

Source: Data processing.

The regression estimate also shows that money supply (LMS), the labor force (LLAB) and capital stock (LCAP) had a positive impact on economic growth. Specifically, the ARDL estimate shows that a one percent increase in money supply, labor force, and the capital stock is expected to increase economic growth by $0.22,4.49$, and 0.06 percent respectively. Furthermore, 
it observes that the inflation rate and interest rate had a negative influence on economic growth, while the effect of exchange rate on economic growth is insignificant. Consequently, a one percent increase in inflation and interest rates is expected to reduce economic growth by 0.004 and 0.019 percent, respectively. The result also shows that the error correction term (ECT(-1)) from the short run ARDL estimate is significant and negatively signed. A highly significant ECM-term proves the existence of a stable long-run relationship (Banerjee \& Newman, 1993). The result of the error correction term implies that the model corrects its short-run disequilibrium by 1.24 percent speed of adjustment towards the long-run equilibrium.

Table 5. Diagnostic Test

\begin{tabular}{ll}
\hline \multicolumn{2}{l}{ Breusch-Godfrey Serial Correlation LM Test } \\
\hline F-Statistics 0.1775 & Prob. F(2,39) 0.8380 \\
Obs*R-squared 0.4241 & Prob. Chi-Square(2) 0.8089 \\
\hline Heteroskedasticity Test: ARCH & \\
\hline F-Statistics 0.0055 & Prob. F(1,31) 0.9414 \\
Obs*R-squared 0.0057 & Prob. Chi-Square(1) 0.9397 \\
\hline
\end{tabular}

Source: Data processing

The study conducts diagnostic tests such as Breusch-Godfrey Serial Correlation LM test and heteroscedasticity ARCH tests to check the validity of the ARDL regression estimate. Table 5 shows that the probability values were higher than 0.05 , indicating the absence of serial correlation in the estimates. The results of the diagnostic tests show the appropriateness of the regression estimates.

Concerning the focus of this study, the regression estimate reveals that export diversification had insignificant influence on economic growth in Nigeria. This result happens because the economy has depended on oil as its primary source of revenue and foreign exchange earning. Meanwhile, the performance of other sectors of the economy has been insignificant in terms of percentage contribution to the real GDP compared to the oil sector. Attempts at diversifying the economy have not yielded meaning results as the economy continued to rely heavily on the oil sector export, which accounted for the insignificant influence of export diversification on economic growth in Nigeria.

However, the positive effect of export diversification on economic growth suggests the need for more intensive diversification strategies by the government in order to obtain a significant influence of export diversification on economic growth in Nigeria. This finding on diversification and economic growth is in line with Aamir (2018) that observes an insignificant-positive relationship between geographical export diversification and economic growth in Pakistan. Nworu (2017) noted that export diversification, particularly in the non-oil sectors, is vital to improving the revenue-based on the government while Kurihara \& Fukushima (2016) observe that greater openness of the economy does not always mean the higher economic growth in emerging and developing countries. While Esu \& Udonwa (2015) observe that economic diversification (proxied by non-oil trade), had a negative 
impact on economic growth. Matadeen (2011) observes that export concentration had a negative impact on economic growth.

Forgha et al., (2014), Hamed et al., (2014), Hodey et al., (2015), and Mudenda et al., (2014), Tadese (2016), and Bilal \& Mohamed (2017) found that there is a positive relationship between export diversification and economic growth. While Olaleye et al. (2013) observe that there is a relationship between export diversification and economic growth in Nigeria, both in the long run and short run, furthermore, Dougruel \& Tekce (2011) observed an inverse relationship between economic growth and export concentration examined for a group of selected MENA countries. Finally, the findings of Agosin (2007) concluded that export diversification significantly influenced the growth of the selected Asian countries that is in contrast to the findings of this study. The export diversification will enhance economic growth (Arip et al., 2010).

\section{Conclusion}

The objective of this study is to investigate the impact of export diversification on economic growth in Nigeria from 1962 to 2016. The study utilized the Auto-Regressive Distributed Lag (ARDL) technique, and the result of the study shows that export diversification is insignificant in influencing economic growth in Nigeria. The outcome of this study shows that export diversification has not enhanced economic growth in Nigeria. Attempts at diversifying the economy have not yielded meaningful result as the economy continued to rely heavily on the oil sector. This result accounted for the insignificant influence of export diversification on economic growth in Nigeria.

The policy implication of this study is that the government should reduce the emphasis on oil production and the unearthing of more oil wells in other regions of the country. There is also the need for conscious economic policies that would promote private investment in other sectors of the economy. The government needs to ensure a stable political atmosphere across the geo-political regions or zones devoid of all forms of crisis, in order to encourage investment in the regions. There is a need for massive investment in Research and Development on modern and efficient production techniques of the various sectors of the economy. Finally, the government needs to explore new marketing areas of exporting other commodities and consumables manufactured goods.

\section{References}

Aamir, H. S. (2018) Export Diversification and growth in Pakistan: An Empirical Investigation from 1972 to 2015, Business \& Economic Review, 10 (1), 107-132.

Agosin, M. R. (2007). Export Diversification and Growth in Emerging Economies. Working paper, 233, Departmento de Economia, Universidad de Chile.

Arip, M. A., Yee, L. S., \& Karim, B. A. (2010). Export Diversification and Economic Growth in Malaysia. MPRA Paper, 20588. Retrieved from: https://mpra.ub.uni-muenchen.de/20588.

Bilal, L., \& Mohamed, K. (2017) Export Diversification and Economic Growth in Morocco: An Econometric Analysis. Applied Economics and Finance, 4(6), 27-35. 
Banerjee, A., \& Newman, A. (1993), Occupational Choice and the Process of Development. Journal of Political Economy, 101 (2), 274-298.

Dougruel, A. S., \& Tekce, M. (2011). Trade Liberalization and Export Diversification in Selected MENA Countries. Topics in Middle Eastern and African Economics, 13, 1-24.

Esu, G. E., \& Udonwa, U. (2015). Economic Diversification and Economic Growth: Evidence from Nigeria. Journal of Economics and Sustainable Development, 6 (16), 56-68.

Forgha, N. G., Sama, M. C., \& Atangana, E. M. (2014). The Effect of Export Diversification on Economic Growth in Cameroon. International Invention Journal of Arts and Social Sciences, 1(3), 54-69.

Hamed, K., Hadi, D., \& Hossein, K. (2014). Export Diversification and Economic Growth in some Selected Developing Countries. African Journal of Business Management, 8(17), 700-704.

Herzer, D., \& Nowak-Lehnmann, F. (2006). What Does Export Diversification Do For Growth? Applied Economics, 38 (15), 1825-1838.

Hodey, L. S., Oduro, A. D., \& Senadza, B. (2015). Export Diversification and Economic Growth in Sub-Saharan Africa. Journal of African Development, 17, 67-81.

Iniodu, P.U. (1995). Diversifying Nigeria's Non-Export Base for Sustainable Development. External Trade and Economic Development in Nigeria. In Annual Conference of the Nigerian Economic Society, pp. 277-285.

Kardyrova, A. (2011). The Effect of Export Diversification on Country Growth, An MA Thesis, Department of Economics, Central European University. Retrieved from: www.etd.ceu.edu/2011/kadyrova_arailym.pdf

Kurihara, Y., \& Fukushima, A. (2016). Openness of the Economy, Diversification, Specialization and Economic Growth. Journal of Economics and Development Studies, 4(1), 31-38.

Matadeen, S. (2011). Export Diversification and Economic Growth: Case Study of a Developing Country Mauritius. In International Conference on International Trade and Investment.

Mudenda, C., Choga, I., \& Chigamba, C. (2014). The Role of Export Diversification and Economic Growth in South Africa. Mediterranean Journal of Social Sciences, 5(9), 705-712.

Nworu, S. C. (2017). Export: Improving Nigerian Government Revenue Base and Economic Diversification. Human Resource Management Research, 7 (1), 65-73.

Olaleye, S. O., Edun, F., \& Taiwo, S. B. (2013) Export Diversification and Economic Growth in Nigeria: An Empirical Test of Relationship Using a Granger Casualty Test. Journal of Emerging Trends in Economics and Management Sciences (JETEMS), 5 (1), 70-79.

Olayiwola, O., \& Okodua, H. (2013). Foreign Direct Investment, Non-Oil Export and Economic Growth in Nigeria: A Causality Analysis. Asian Economic and Financial Review, 3 (11), 1479-1496.

Suberu, O. J., Ajala, O. A., Akande, M. O., \& Olure-Bank, A. (2015). Diversification of the Nigerian Economy Towards a Sustainable Growth and Economic Development. International Journal of Economics, Finance, and Management Sciences, 3(2), 107-114.

Tadese, G. T. (2016) The Contribution of Export Diversification for Economic Growth in Ethiopia. Journal of Economics and Sustainable Development. 7(21), 21-25. 